\title{
PLENODOMUS MELILOTI DEARNESS \& SANFORD FOUND IN FINNISH LAPPLAND
}

\author{
ARVi Salonen \\ Department of Plant Pathology, University of Helsinki
}

Received June 29, 1962

At the experimental station of the University of Helsinki located at Muddusniemi, Inari $\left(69^{\circ} 5^{\prime} \mathrm{N}\right)$, it was observed in the spring 1953 that the roots of dead red clover plants contained small, darkcolored formations resembling sclerotia (5). The same fungus occurred even more abundantly in the spring 1961. During both winters, $1952-53$ and $1960-61$, there were especially large amounts of low temperature parasitic fungi. Thus, in the spring 1961 Sclerotinia borealis Bubak \& Vleugel caused almost the complete destruction of first-year timothy leys and had badly damaged older leys. In addition, stands of red clover, which generally overwinter well at Muddusniemi $(5,6,7)$, were found to be severely injured. For example, in the red clover sowing time trial (sowing dates 15. 6. 1960 and 15. 7. 1960), all the clover varieties, including the Finnish variety Tammisto, were completely destroyed in the course of the winter.

In investigating the cause of the clover destruction, it was found that the fungal growths observed on the roots of dead clover plants were black, hard, slightly flattened spherical formations, $5-11 \mathrm{~mm}$ in diameter. They occurred in all parts of the surface of dark-colored, dead roots, but they were most numerous in the upper parts of the roots, where they appeared as dense clusters (Fig. 1).

The fungus was isolated on Henneberg agar (2) in Petri dishes and was cultured at temperatures of $+2^{\circ} \mathrm{C},+7^{\circ} \mathrm{C}$ and $+22^{\circ} \mathrm{C}$. On the basis of the culture tests as well as the symptoms observed in the roots of infected clover plants, it was possible to determine this fungus as being Plenodomus meliloti Dearness \& Sanford $(1,4)$. This fungus belongs to the Sphaeropsidales order of the Fungi Imperfecti.

When cultured on Henneberg agar at $+2^{\circ} \mathrm{C}$ and $+7^{\circ} \mathrm{C}$, Plenodomus meliloti had a dense mycelial growth with radial furrows and a gray color (Fig. 2). The pycnidia, which were formed in large numbers, contained at first mycelial tissue. Gradually they became projecting, bluish gray in color, without an aperture. At this stage they resembled small sclerotia. After $40-50$ days of cultivation the pycnidia 


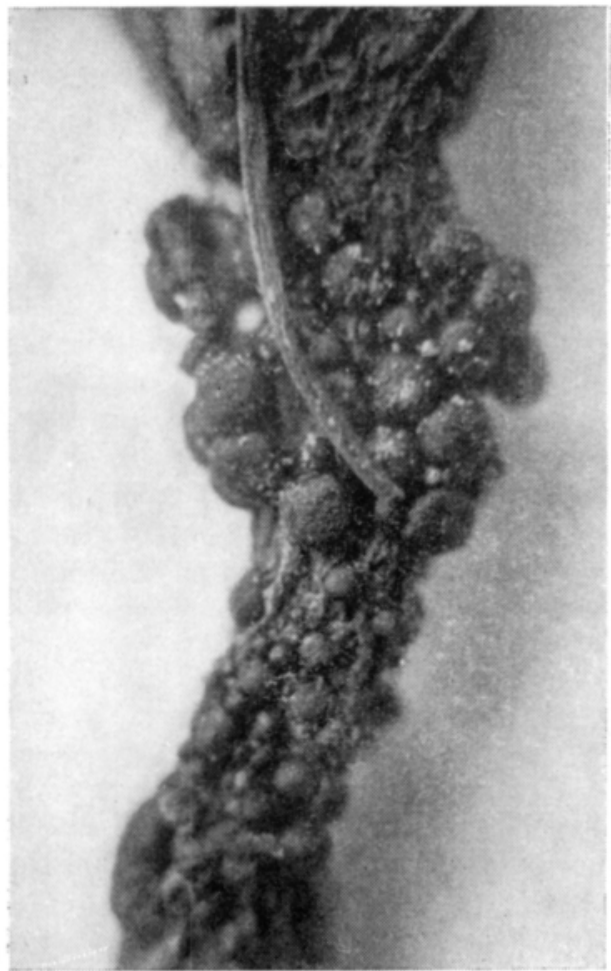

Fig. 1. Pycnidial structures, resembling sclerotia, on the root of a dead red clover plant. $\mathbf{x} 10$.

became black and developed apertures. The pycnidia occurred sometimes as single, slightly flattened spheres (Fig. 3, a and b) and sometimes in large, usually elongated clusters in which the individual pycnidia were either clearly distinct from one another (Fig. 3, c) or were completely merged together in a uniform structure. The diameter

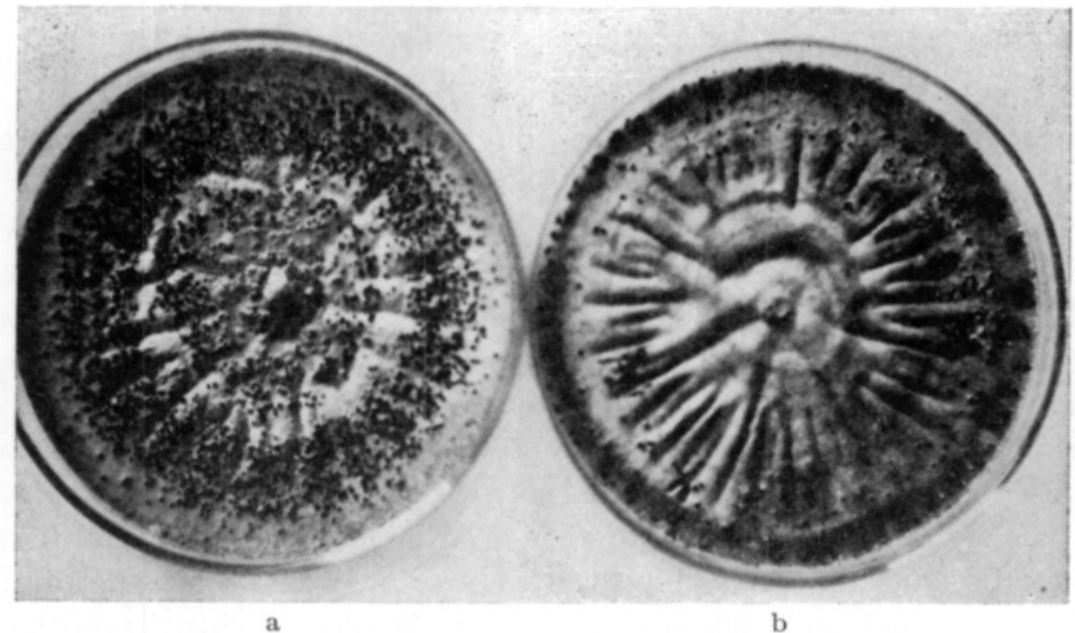

Fig. 2. 65-day old cultures of Plenodomus meliloti on Henneberg agar. a) $\left.+7^{\circ} \mathrm{C}, \mathrm{b}\right)+22^{\circ} \mathrm{C}$. 
of the pycnidia varied from 500 to $800 \mu$. There were generally several spore chambers and apertures in each pycnidium so that the pycnidia cluster as a whole contained relatively many apertures. These were located either directly on the surface of the pycnidia or on the tubular, slightly curved terminal elongation formed by them. Conidiospores were produced on very short, unbranched conidiophores located in the spore chambers of the pycnidia. About 60-80 days after the culture growth had terminated, the spores began to flow from the apertures as a yellow secretion. The spores were colorless, single-celled and elongated $(4.5-6.5 \times 2.0-3.3 \mu$; average $5.29 \times 2.59 \mu$; Fig. 3, d).

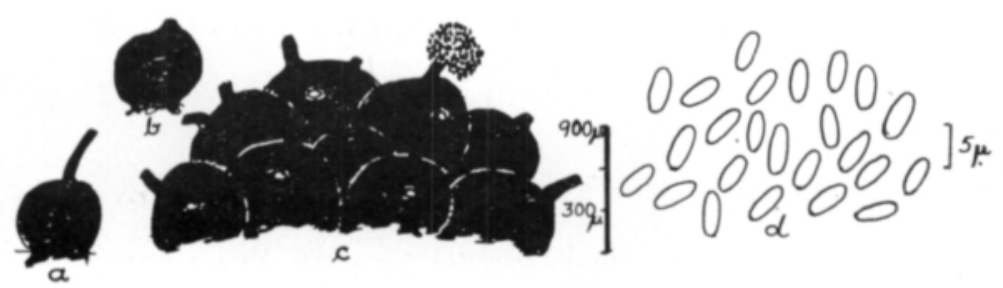

Fig. 3. Plenodomus meliloti. $\mathrm{a}, \mathrm{b}=$ single pycnidia; $\mathrm{c}=$ pycnidia cluster; $\mathrm{d}=$ conidiospores. Drawings made from 65-day old culture on Henneberg agar.

At a temperature of $+22^{\circ}$ the vegetative growth of $P$. meliloti was the same as at the lower temperatures. On the other hand, only few pycnidia were formed (Fig. 2, b). According to the investigations of SANFORD (4) the temperature limits for this fungus are $0^{\circ}$ and $27^{\circ} \mathrm{C}$ with the optimum being $+15^{\circ}-+17^{\circ} \mathrm{C}$.

P. meliloti is a low temperature parasitic fungus. It had previously been found only in the provinces of Alberta and Saskatchewan in Canada (4) and in Alaska (3). It has been determined to be pathogenic to species belonging to the genera Melilotus and Medicago as well as to Trifolium partense. In addition, SANFORD (4) has found it as a saprophyte in the roots of oats, while LEBEAU and LogSDon (3) have encountered it in Festuca rubra and Poa pratensis.

In field legumes $P$. meliloti is a parasite mainly of weak plants (3), and plants with a small root system may be completely destroyed by this fungus. It attacks the roots of the plants in the latter part of the winter, producing dark-colored, necrotic lesions in which pycnidia are usually formed. If environmental conditions become unfavorable for the development of the fungus, it may remain at the sclerotia stage. According to SANFORD (4) P. meliloti survives in the soil and is spread in the form of imperfectlydeveloped, closed, leathery pycnidia.

\section{LITERATURE}

(1) Dearness, J. \& Sanford, G. B. 1930. A new species of Plenodomus. Ann. Myc. 28: 324-325.

(2) Henneberg, W. 1909. Nährungsbakteriologische Praktikum. Betriebsuntersuchungen und Pilzkunde, 670 s. Berlin.

(3) Lebeau, J. B. \& Logsdon, Ch. E. 1958. Snow mold of forage crops in Alaska and Yukon. Phytopath. 48: $148-150$. 
(4) SAnford, G. B. 1933. A root rot of sweet clover and related crops caused by Plenodomus meliloti Dearness and Sanford. Can. J. of Res. 8: 337-348.

(5) Pohjakallio, O. \& Salonen, A. 1956. Orientoitumisvaiheen tulokset Muddusniemen koetilan nurmikasvitutkimuksissa. Maat.tiet. aikak. 28: 1-7.

(6) _- 1958. Kymmenen vuotta kenttäkoetoimintaa Muddusniemen koetilalla Lapissa. Maatal. ja koetoim. 12: $42-54$.

(7) - - 1959. Puna-apilan viljelyn mahdollisuuksista Taka-Lapissa. Ibid. 13: 179-186.

\section{SELOST US :}

\section{PLENODOMUS MELILOTI DEARNESS \& SANFORD LOYTYNYT SUOMEN LAPISTA.}

\section{ARVi SALONen}

\section{Yliopiston kasvipatologian laitos, Helsinki}

Helsingin yliopiston kasvipatologian laitoksen koekentällä Muddusniemen koetilalla $\left(69^{\circ} 5^{\prime} \mathrm{N}\right)$ Inarissa todettiin keväällä 1953, että kuolleiden apilain juurissa oli pieniä, tummia sklerootiomaisia muodostumia (5). Niitä oli kaikkialla ruskettuneiden juurien pinnalla, mutta erityisesti juurien yläosassa, jossa ne näkyivăt tiheinä ryhminä (kuva 1). Samaa sientä ilmeni vielä runsaammin keväällä 1961. Molempina talvina, $1952-53$ ja $1960-61$, esiintyi talvituhosieniä erityisen runsaasti.

Sieni eristettiin ja suoritettujen kasvatuskokeiden sekä puna-apilain juurissa esiintyneiden symptomien perusteella todettiin, että se oli Plenodomus meliloti Dearness \& Sanford $(1,4)$. Tämä laji kuuluu Fungi imperfecti-sienten Sphaeropsidales-lahkoon.

Plenodomus meliloti on talvituhosieni; aikaisemmin sitä on tavattu vain Kanadassa, Albertan ja Saskatchewanin valtioissa (4) sekä Alaskassa (3). Sieni on osoittautunut patogeeniseksi Melilotus- ja Medicago-sukuihin kuuluville lajeille sekä Trifoliorum pratenselle, Sienen ei ole todettu leviävän siementavarassa (4). 